\title{
TINJAUAN HUKUM BAGI TENAGA KERJA WANITA (TKW) DALAM HUKUM ISLAM
}

\author{
Muhammad Ilham \\ Universitas Islam Negeri Alauddin Makassar \\ Jln Sultan Alauddin No.63, Gowa - Sulawesi Selatan \\ ilhamsmsfc16@gmail.com
}

\section{Abstract:}

Pengangguran sampai saat ini masih menjadi problem krusial pemerintah Indonesia. Tak dapat dipungkiri, masalah ini terjadi akibat tingginya pertumbuhan angkatan kerja yang tidak diimbangi dengan kemampuan pemerintah untuk menyediakan lapangan pekerjaan. Kondisi akhirnya menjadi pemicu terjadinya mobilisasi tenaga kerja secara masal antar negara yang dilakukan oleh pemerintah. Untuk mengurangi angka pengangguran, pemerintah melaksanakan program penempatan Tenaga Kerja Indonesia (TKI) ke luar negeri. Namun banyaknya kasus Tenaga Kerja Wanita (TKW) Indonesia yang bekerja di luar negeri seperti terjadinya pelecehan seksual, pemerkosaan, kekerasan, pembunuhan, pemotongan upah, dan pungutan liar bahkan yang dipidana dengan hukuman mati menjadi bukti nyata bahwa pemerintah Indonesia belum maksimal dalam menangani dan membantu para Tenaga Kerja Wanita (TKW) Indonesia untuk bebas dari jeratan hukuman di luar negeri. Pemerintah seharusnya bersikap proaktif dalam memberi perlindungan hukum dengan cara memperkuat diplomasi antarnegara dan menjalin komunikasi yang baik sehingga dapat lebih menjamin perlindungan terhadap hak-hak para TKW Indonesia di luar negeri. Adapun menurut hukum Islam menjadi TKW yang bekerja di luar negeri hukumnya haram, berdasarkan 2 (dua) alasan utama, Pertama: Karena 
TKW telah bekerja di luar negeri tanpa disertai mahram atau suaminya. Kedua: Menjadi TKW juga haram ditinjau dari segi lain, yaitu keberadaan TKW telah menjadi perantaraan munculnya berbagai hal yang diharamkan syara'. Misalnya, terjadinya pelecehan seksual, pemerkosaan, kekerasan, pembunuhan, pemotongan upah, dan pungutan liar. dalam kaidah fikih Al-Dharar yuzaal (segala macam bahaya wajib dihilangkan).

\section{Keywords: Tenaga Kerja Wanita (TKW), Hukum Islam.}

\section{Pendahuluan}

Kemiskinan telah mengakibatkan munculnya serangkaian problem sosial. Judi, pasang togel, penjambretan, penodongan dan prostitusi, seringkali dilakukan justru oleh orang-orang miskin yang kehilangan akal untuk menolong dirinya sendiri. Orang kaya bermental miskin pun membuat semakin kompleksnya persoalan ini. Bagi perempuan, persoalan kemiskinan menjadi lebih rumit. Karena kemiskinan seringkali membuat mereka kehilangan integritas atas diri dan tubuhnya sendiri. Sebagian perempuan rela jadi istri simpanan, istri kedua, ketiga dan seterusnya atas dasar persoalan ekonomi. Sebagian yang lain terjebak dalam dunia perbudakan, termasuk perbudakan seksual bentuk baru. Menjadi korban trafficking dan masuk ke dalam jerat dunia prostitusi.

Persoalan Perempuan Pekerja Migran (TKW) merupakan gambaran konkrit kemiskinan perempuan. Kompleksitas persoalan ini melibatkan berbagai pihak dan menjadi persoalan sistem dan struktural dengan faktor penyebab dan kendala yang tidak tunggal. Oleh keluarganya TKW dijadikan obyek/komoditas untuk melepaskan diri dari lingkaran kemiskinan. Tergiur oleh janji-janji pekerjaan yang baik di kota, mereka terpaksa menjadi buruh yang diupah teramat rendah dengan beban kerja berlebihan dan hampir tanpa jaminan keamanan. Pembantu 
rumah tangga dengan jam kerja yang tidak jelas dan rentan menjadi korban kekerasan domestik. Menjadi TKW yang minim perlindungan dan seringkali menjadi korban kekerasan serta pemerasan baik di negeri sendiri maupun di negeri orang. Tak jarang, anak perempuan menjadi pihak yang dikorbankan oleh orang tuanya sendiri sebagai alat pembayar hutang melalui 'kawin paksa' sebagai modus operandi-nya. Mirip dengan kisah Siti Nurbaya yang terpaksa kawin dengan Datuk Maringgih untuk melunasi hutang ayahnya.

Kasus Tenaga Kerja Wanita (TKW) Indonesia yang bekerja di luar negeri adalah masalah aktual yang seakan tak pernah berhenti dibahas. Sepanjang tahun pemerintah Indonesia selalu dipusingkan dengan permasalahan TKW. Sepanjang tahun pula, pemerintah harus berselisih dengan Negara pengimpor TKW karena kasus-kasus kekerasan dan pedeportasian para tenaga kerja kita. Dan sepanjang tahun pula, tak ada solusi dan kebijakan yang tepat sasaran dan mampu mengatasi permasalahan TKI dan TKW ini. Setiap kebijakan yang dikeluarkan pemerintah menuai protes dari banyak kalangan aktivis perempuan, akademisi dan pemerhati TKW. Sehingga seolah kebijakan yang sudah ada mengambang begitu saja tanpa tindak lanjut, sementara nasib para TKW semakin tragis dan terkesan dibiarkan.

\section{Pengertian Tenaga Kerja}

Tenaga kerja dalam pengertian hidup bermasyarakat diartikan sebagai setiap orang yang mampu melakukan pekerjaan guna menghasilkan barang ataupun jasa untuk memenuhi kebutuhan sendiri atau masyarakat. ${ }^{1}$ dalam hal ini berarti setiap orang tanpa terkecuali baik pria maupun wanita selama mereka mampu melakukan pekerjaan untuk menghasilkan barang

${ }^{1}$ Lihat Undang-Undang No. 13 tahun 2003 Bab I pasal 1 ayat 2 tentang Ketenagakerjaan.

Sangaji Jurnal Pemikiran Syariah dan Hukum 
ataupun jasa baik untuk memenuhi kebutuhan sendiri maupun untuk masyarakat termasuk tenaga kerja.

Seseorang dalam melakukan suatu pekerjaan dapat dibedakan menjadi 2 (dua) bagian macam yaitu untuk melakukan pekerjaan untuk dirinya sendiri dan melakukan pekerjaan untuk dilaksanakan dalam suatu hubungan kerja, yang mana si pekerja mendapatkan upah dan orang lain yang bertindak sebagai pemberi kerja di bawah perintah orang lain dan hasilnya pun untuk bukan dirinya sendiri tetapi untuk orang lain. ${ }^{2}$

Adapun tenaga kerja menurut para ahli antara lain:

1. Tenaga kerja menurut Hamzah adalah tenaga yang bekerja di dalam maupun di luar hubungan kerja dengan alat produksi utama dalam prosesproduksi baik fisik maupun pikiran.

2. Menurut Suparmoko dan Icuk Rangga Bawono, tenaga kerja adalah penduduk berusia kerja yang memiliki pekerjaan dan melakukan kegiatan-kegiatan lainnya.

3. Sedangkan menurut Payman, tenaga kerja adalah produk yang telah bekerja, mencari pekerjaan atau sebagai pelaksana pekerjaan. ${ }^{3}$

4. Menurut Payaman J. Simanjuntak bahwa pengertian tenaga kerja adalah mencakup penduduk yang sudah atau sedang bekerja, yang sedang mencari kerja dan yang melakukan pekerjaan lain seperti sekolah dan mengurus rumah tangga. ${ }^{4}$

5. Menurut UU No. 13 tahun 2003 Bab I pasal 1 ayat 2 disebutkan bahwa tenaga kerja adalah setiap orang yang

2Imam Soepomo, Pengantar Hukum Perburuhan (Jakarta: Djambatan, 1992), h. 3.

${ }^{3}$ http://dilihatya.com/1762/pengertian-tenaga-kerja-menurut-para-ahli. diakses pada tanggal 2 Mei 2017, Pukul 11:10.

${ }^{4}$ Lalu Husni, Hukum Ketenagakerjaan Indonesia(Jakarta;PT. Raja Grafindo Persada,2007), h. 17. 
mampu melakukan pekerjaan guna menghasilkan barang dan atau jasa baik untuk memenuhi kebutuhan sendiri maupun untuk masyarakat. ${ }^{5}$

Adapun batas umur seseorang dikatakan sebagai tenaga kerja dalam Pasal 68 UU No. 13 tahun 2003 menyebutkan bahwa pengusaha dilarang mempekerjakan anak. Dalam ketentuan undang-undang tersebut anak adalah setiap orang yang berumur di bawah 18 tahun. Berarti 18 tahun adalah usia minimum yang diperbolehkan pemerintah untuk bekerja. ${ }^{6}$

Kemudian pengertian pekerja atau buruh menurut Pasal 1 angka 3 Undang-Undang No. 13 tentang ketenagakerjaan menyebutkan bahwa pekerja atau buruh adalah setiap orang yang bekerja dengan menerima upah atau imbalan dalam bentuk lain. ${ }^{7}$

Adapun kriteria angkatan kerja untuk memasuki dunia kerja antara lain:

1. Jenis dan tingkat pendidikan

2. Keahlian khusus yang dimiliki calon tenaga kerja

3. Kejujuran, sikap, serta kepribadian

4. Pengalaman kerja

5. Kesehatan. ${ }^{8}$

Tenaga kerja meliputi tenaga kerja laki-laki dan tenaga kerja perempuan, mengenai tenaga kerja perempuan dalam hokum ketenagakerjaan dan peraturan perundang-undangan tidak ada

5Pasal 1undang-Undang Ketenagakerjaan No. 13 tahun 2003.10 Pasal 68 Undang-UndangKetenagakerjaan No. 13 tahun 2003.

6Pasal 68 Undang-UndangKetenagakerjaan No. 13 tahun 2003.

${ }^{7}$ Lalu Husni, Hukum Ketenagakerjaan Indonesia, h. 19.

${ }^{8}$ http/ilhamrizki.com/2013/criteria dasar memilih calon tenaga kerja. diakses pada tanggal 2 Mei 2017, Pukul 11:15.

Sangaji Jurnal Pemikiran Syariah dan Hukum 
pengertian khusus, karena tenaga kerja yang dimaksud adalah meliputi pekerja laki-laki dan pekerja perempuan.

Pekerja perempuan sebagai sosok seorang perempuan yang hidup dalam kodrati perempuan, tata hidupnya juga dipengaruhi oleh lingkungan eksternalnya. Menurut Abdul rahman budiono yang dimaksudkan perempuan di sini adalah perempuan yang telah berumur 18 tahun atau lebih .9

Dalam Pasal 76 ayat (1) Undang-undang Ketenagakerjaan menyebutkan pekerja atau buruh perempuan yang berumur kurang dari 18 (delapan belas) tahun dilarang dipekerjakan antara pukul 23.00 sampai dengan pukul 07.00. ${ }^{10}$

Pembatasan dan larangan bagi pekerja perempuan untuk menjalankan pekerjaan sebagaimana disebutkan di atas dimaksudkan untuk melindungi pekerja perempuan itu sendiri dari norma kesusilaan maupun untuk menjaga fisiknya karena secara kodrati fisik wanita lebih lemah dibandingkan dengan pria. ${ }^{11}$

Sedangkan Calon Tenaga Kerja Indonesia yang selanjutnya disebut calon TKI adalah setiap warga negara Indonesia yang memenuhi syarat sebagai pencari kerja yang akan bekerja di luar negeri dan terdaftar di instansi pemerintah kabupaten/kota yang bertanggung jawab di bidang ketenagakerjaan.

Tenaga kerja Indonesia yang selanjutnya disebut TKI adalah setiap warga negara Indonesia yang memenuhi syarat untuk bekerja di luar negeri dalam hubungan kerja untuk jangka waktu tertentu dengan menerima upah. ${ }^{12}$

9Suratman, Hukum Ketenagakerjaan Indonesia(Jakarta: PT. Indeks, 2010), h. 30.

10Pasal 76 undang-undang ketenagakerjaan No. 13 tahun 2003.

11Suratman, Hukum Ketenagakerjaan Indonesia, h.31.

${ }^{12}$ Pasal 1 Undang-undang Penempatan dan Perlindungan Tenaga Kerja Indonesia di LuarNegeri No. 39 Tahun 2004. 
Adapun tenaga kerja, ada yang bekerja di dalam negeri dan ada pula yang bekerja di luar negeri. Adapun perekrutan diluar negeri menurut pasal 35 Undang-Undang Nomor 39 Tahun 2004 tentang penempatan dan perlindungan tenaga kerja Indonesia di luar negeri menentukan bahwa; Perekrutan calon TKI yang telah memenuhi persyaratan:

1. Berusia sekurang-kurangnya 18 (delapan belas) tahun kecuali bagi calon TKI yang akan dipekerjakan pada pengguna perseorangan sekurang-kurangnya berusia 21 (dua puluh satu) tahun;

2. Sehat jasmani dan rohani;

3. Tidak dalam keadaan hamil bagi calon tenaga kerja perempuan dan;

4. Berpendidikan sekurang-kurangnya lulus Sekolah Lanjutan Tingkat Pertama (SLTP) atau yang sederajat.

Bagi warga Negara Indonesia yang memenuhi parsyaratan di atas dapat mencari kartu kuning (kartu pertanda pencari pekerjaan) yang dikeluarkan oleh Dinas Tenaga Kerja Kabupaten. ${ }^{13}$

Bagi warga Negara Indonesia yang mempunyai persyaratan di atas dapat mencari Kartu Kuning (kartu pertanda pencari pekerjaan) yang dikeluarkan oleh Dinas Tenaga Kerja setiap kabupaten. Untuk itu setiap calon TKI/TKI mempunyai hak dan kesempatan yang sama untuk:

1. Bekerja di luar negeri;

2. Memperoleh informasi yang benar mengenai pasar kerja luar negeri dan prosedur penempatan TKI di luar negeri;

13Pasal 35 Undang-undang Penempatan dan Perlindungan Tenaga Kerja Indonesia di LuarNegeri No. 39 Tahun 2004.

Sangaji Jurnal Pemikiran Syariah dan Hukum 
3. Memperoleh pelayanan dan perlakuan yang sama dalam penempatan diluar negeri;

4. Memperoleh kebebasan menganut agama dan keyakinan serta kesempatan untuk menjalankan ibadah sesuai dengan agama dan keyakinan yang dianutnya;

5. Memperoleh upah sesuai dengan standar upah yang berlaku di Negaratujuan;

6. Memperoleh hak, kesempatan, dan perlakuan yang sama yang diperoleh tenaga kerja asing lainnya sesuai dengan peraturan perundang-undangan di negara tujuan;

7. Memperoleh jaminan hukum sesuai dengan peraturan perundang undangan atas tindakan yang dapat merendahkan harkat dan martabatnya serta pelanggaran atas hak-hak yang ditetapkan sesuai dengan peraturan perundang-undangan selama penempatan di luar negeri;

8. Memperoleh jaminan perlindungan keselamatan dan keamanan kepulangan TKI ke tempat asal;

9. Memperoleh naskah perjanjian kerja yang asli. ${ }^{14}$

Kehadiran sebuah Undang-undang dalam rangka penempatan dan perlindungan TKI yang bekerja di luar negeri sudah lama dinantikan karena pengaturan penempatan dan perlindungan TKI ke luar negeri sudah seharusnya diatur dengan undang-undang karena:

1. Bekerja merupakan hak asasi manusia yang wajib dijunjung tinggi, dihormati, dan dijamin penegakannnya;

2. Hak setiap warga Negara untuk memperoleh pekerjaan dan penghidupan yang layak baik di dalam maupun di luar negeri

${ }^{14}$ Pasal 8 Undang-undang Penempatan dan Perlindungan Tenaga Kerja Indonesia di LuarNegeri No. 39 Tahun 2004. 
sesuai dengan keahlian, keterampilan, bakat, minat, dan kemampuan;

3. Dalam kenyataan selama ini tenaga kerja Indonesia yang bekerja di luar negeri sering dijadikan objek perdagangan manusia, kerja paksa, korban kekerasan, kejahatan atas harkat dan martabat manusia serta perlakuan lain yang bertentangan dengan hak asasi manusia;

4. Negara wajib menjamin dan melindungi hak asasi warga negaranya yang bekerja baik di dalam maupun di luar negeri berdasarkan prinsip persamaan hak, demokrasi, keadilan sosial, kesetaraan gender, dan anti diskriminasi;

5. Penempatan tenaga kerja Indonesia ke luar negeri perlu dilakukan secara terpadu antara instansi pemerintah pusat maupun daerah dan peran serta masyarakat dalam suatu produk hukum yang memadai guna memberikan perlindungan yang maksimal. ${ }^{15}$

Dengan demikian penempatan tenaga kerja Indonesia untuk bekerja di luar negeri merupakan suatu upaya untuk mewujudkan hak dan kesempatan yang sama bagi tenaga kerja untuk memperoleh pekerjaan dan penghasilan yang layak yang di dalam pelaksanaannya harus dilakukan dengan memperhatikan harkat, martabat, manusia serta sisi perlindungan hukumnya. Karena itu negara wajib secara aktif menjamin dan melindungi hak asasi warga negara yang bekerja baik di dalam maupun di luar negeri berdasarkan prinsip persamaan hak, demokrasi, keadilan social, kesetaraan gender, dan anti perdagangan manusia. ${ }^{16}$

${ }^{15}$ Lalu Husni, Hukum Ketenagakerjaan Indonesia, h. 87-88.

${ }^{16}$ Lalu Husni, Hukum Ketenagakerjaan Indonesia, h. 89.

Sangaji Jurnal Pemikiran Syariah dan Hukum 


\section{Tenaga Kerja Wanita (TKW) dalam Hukum Islam}

TKW (Tenaga Kerja Wanita) adalah TKI (Tenaga Kerja Indonesia) perempuan warga negara Indonesia yang bekerja di luar negeri dalam hubungan kerja untuk jangka waktu tertentu dengan menerima upah. TKW sering disebut pahlawan devisa karena dalam setahun dapat mengirimkan uang hingga US\$ 8,7 miliar atau Rp 126 triliun (data 2017). Pengiriman uang (remitansi) oleh Tenaga Kerja Indonesia (TKI) ke Tanah Air sudah mencapai Rp 40 triliun atau US\$ 2,8 miliar [Kurs US\$1 = Rp 14.500] selama kuartal II-2018.Angka tersebut jauh lebih tinggi dari kuartal I-2018 yang hanya sebesar US\$2,6 miliar atau Rp 38 triliun. ${ }^{17}$

Bagi Indonesia karena begitu banyak TKW yang menghadapi kesulitan, termasuk karena banyak yang tidak mempunyai paspor, izin masuk dari negara yang dimasuki, malah ada yang sama sekali menjadi migran ilegal. Di antara yang sangat menderita itu, tampaknya adalah TKW ilegal, yang bagai tidak dapat dilindungi oleh negeri asal, dan tidak pula dapat dilindungi oleh negeri tetangga.

Berbagai masalah sering menimpa TKW baik di dalam maupun di luar negeri. Misal: pelecehan seksual, perkosaan, penganiayaan fisik (kekerasan), pembunuhan, pemotongan upah, dan pungutan liar oleh pejabat dan agen terkait. Bahkan sepanjang tahun 2009-2010 saja, disebut-sebut hampir sekitar 4000 TKW menjadi korban penipuan, pemerasan, pelecehan seksual, kekerasan, hingga pembunuhan.

Hal yang sangat disayangkan adalah bahwa ternyata kasuskasus kekerasan yang mereka alami kurang mendapat perhatian dari pemerintah (dengan berbagai macam alas an).Bahkan, sampai ketika beberapa TKW di Arab Saudi yang di hukum matipun, pemerintah tidak sanggup berbuat apa-apa. Padahal,

17https://www.cnbcindonesia.com/news/20180818113018-4-29164/tkikirim-uang-hingga-rp-40-t-di-kuartal-ii-2018. 
secara tidak langsung, para TKW ini telah menyumbangkan banyak sekali devisa bagi Negara. ${ }^{18}$

Misalnya saja kasus penyiksaan terhadap tenaga kerja wanita (TKW) yang bekerja di luar negeri terus terjadi. Selain itu, tak sedikit pekerja migran asal Indonesia yang mencari nafkah di negara lain dilaporkan menghilang. Bahkan, ada pula yang pulang nama alias meninggal atau tewas saat bekerja sebagai pembantu rumah tangga di luar negeri.

Peristiwa seperti ini sudah terjadi sejak lama dan selalu berulang.Kondisi itu mengundang keprihatinan berbagai elemen bangsa.Sejumlah Ormas perempuan Islam mendesak Pemerintah RI untuk menghentikan pengiriman TKW ke luar negeri untuk sementara waktu.Bahkan, ada pula yang mendesak agar dihentikan selamanya.

Menjadi TKW yang bekerja di luar negeri hukumnya haram, berdasarkan 2 (dua) alasan utama:

Pertama: karena TKW telah bekerja di luar negeri tanpa disertai mahram atau suaminya. Padahal syara' telah mengharamkan seorang perempuan muslimah melakukan perjalanan (safar) sehari semalam tanpa disertai mahram atau suami, meski untuk menunaikan ibadah haji yang wajib. ${ }^{19}$

Dalam masalah ini Imam Ibnu Qudamah menyatakan siapa saja perempuan yang tidak punya mahram dalam perjalanan haji, tidak wajib naik haji. (Al-Mughni, 5/30). Dalilnya adalah sabda Rasulullah saw.,

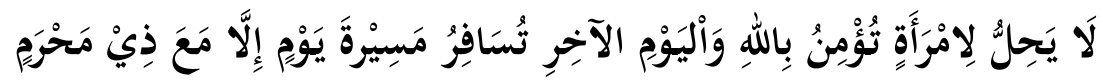

${ }^{18}$ R. Subekti R. Tjitrosono. .Kitap undang-undang perdata (Jakarta:Pradayana Paramita,1963), h. 327.

${ }^{19}$ Lihat Imad Hasan Abul 'Ainain; 'Amal Al-Mar'ah fi Mizan Al-Syari'ah Al-Islamiyah, h. 42. Lihat M. Ali al-Bar, Amal Al-Mar'ah fi Al-Mizan, h. 29. Lihat Riyadh Muhammad Al-Musaimiri, 'Amal Al-Mar'ah Bayna Al-Masyru' wa AlMamnu', h. 22. Lihat Taqiyuddin an-Nabhani, An-Nizham al-Ijtima'i fi Al-Islam, h. 35.

Sangaji Jurnal Pemikiran Syariah dan Hukum 
Terjemahannya:

"Tidak halal perempuan yang beriman kepada Allah dan Hari Akhir melakukan perjalanan selama sehari semalam kecuali disertai mahramnya." (HR Bukhari no 1088; Muslim no 1339; Abu Dawud no 1723; Tirmidzi no 1170; Ibnu Majah no 2899; Ahmad no 7366).

Berdasarkan hadits ini, haram hukumnya menjadi TKW di luar negeri.Karena umumnya TKW tidak disertai mahram atau suaminya dalam perjalanannya ke luar negeri.TKW itu pun tetap dianggap musafir yang wajib disertai mahram atau suaminya, selama dia tinggal di luar negeri hingga dia kembali ke negeri asalnya (Indonesia). ${ }^{20}$

Kedua: menjadi TKW juga haram ditinjau dari segi lain, yaitu keberadaan TKW telah menjadi perantaraan munculnya berbagai hal yang diharamkan syara'. Misalnya, terjadinya pelecehan seksual, pemerkosaan, kekerasan, pembunuhan, pemotongan upah, dan pungutan liar.Semua ini telah diharamkan oleh syara' berdasarkan dalilnya masing-masing. Maka, menjadi TKW hukumnya haram berdasarkan kaidah fiqih Al-Wasilah ila al-Haram Muharramah(segala perantaraan yang mengakibatkan terjadinya keharaman, hukumnya haram). ${ }^{21}$

Atas dasar dua alasan ini, haram hukumnya menjadi TKW yang bekerja di luar negeri.Pengiriman TKW ke luar negeri pun wajib dihentikan, sesuai kaidah fiqih Al-Dharar yuzaal (segala macam bahaya wajib dihilangkan). ${ }^{22}$

Problem TKI sangat kompleks.Semua permasalahan ini harus segera disolusikan dengan sistem yang benar, yaitu sistem Islam agar semua permasalahan ini tuntas dan tidak terulang lagi

${ }^{20}$ Mahmud Abdul Lathif Uwaidhah, Al-Jami' li Ahkam Al-Shalah, h. 337.

${ }^{21}$ Lihat M. Shidqi Burnu, Mausu'ah Al-Qawa'id al-Fiqhiyyah, h.199.

${ }^{22}$ Lihat Imam Suyuthi, Al-Asybah wa Al-Nazha ir, h. 83. Lihat M. Bakar Ismail, Al-Qawa'id Al-Fighiyyah Bayna Al-Ashalah wa Al-Taujih, h. 99. 
kasusnya. Semua itu tidak akan bisa sempurna diwujudkan kecuali dengan penerapan syariah Islam secara total dan menyeluruh (kaffah) oleh seorang Khilafah dalam bingkai Daulah al-Khilafah ar-Rasyidah 'ala Minhaj an-Nubuwah.

Diantara hujjah yang tidak memperbolehkan menjaidi TKW adalah sebagai berikut:

Di dalam "Shohihul Bukhoriy" dari hadits Abdullah bin 'Abbas bahwa Rasulullah Shollallohu 'Alaihi wa Sallam berkata:

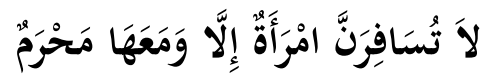

Terjemahannnya:

"Janganlah seorang wanita safar melainkan bersamanya mahrom".

Wanita yang melakukan ibadah seperti haji saja tidak diperbolehkan berangkat melainkan ditemani mahromnya, lalu bagaimana dengan melakukan pekerjaan di luar negri?.

Al-Bukhari meriwayatkan dari hadits Abu Sa'id AlKhudriy dan hadits Abdulloh bin 'Abbas bahwa Rasulullah Shollallohu 'Alaihi wa Sallam berkata:

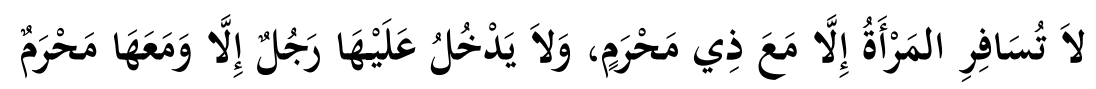

Terjemahannya:

Janganlah seorang wanita safar melainkan bersamanya mahrom, dan janganlah seseorang masuk kepadanya melainkan bersamanya mahrom". Maka seseorang berkata: "Wahai Rasululloh sesungguhnya saya ingin untuk keluar ke peperangan ini dan itu, dan istriku menginginkan untuk haji? Maka beliau Shollallohu 'Alaihi wa Sallam berkata:

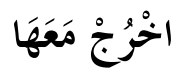

"Keluarlah kamu bersamanya (untuk menunaikan ibadah haji)!”.

Kalaupun seandainya ada wanita yang pergi ke luar negri untuk bekerja dan dia diantar oleh mahramnya lalu mahramnya 
kembali maka ini tidak cukup, melainkan mahramnya harus tinggal bersamanya di negri tersebut atau kalau dia memiliki rumah sendiri di negri tersebut maka boleh baginya untuk tinggal sendirian di negri tersebut walaupun mahramnya meninggalkannya, hal ini sebagaimana yang pernah dilakukan oleh Nabiullah Ibrahim 'alaihis salam, beliau membawa istrinya Hajar bersama putranya Isma'il lalu keduanya ditinggal di Makkah, ketika ditinggal pergi oleh Ibrahim 'alaihis salam maka Ummu Isma'il Hajar Radhiyallohu 'anha berkata:

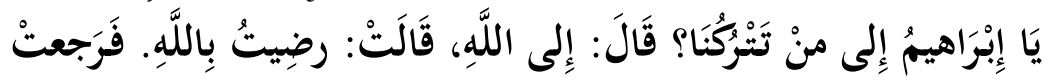

Terjemahannya:

Wahai Ibrohim kepada siapa kamu meninggalkan kami?" beliau berkata: "Kepada Allah", maka ia berkata: "Aku ridha kepada Allah", lalu dia kembali (ke tempat tinggalnya di sisi air Zamzam di Makkah). Diriwayatkan oleh alBukhari dari Abdullah bin 'Abbas.

Nabiullah Ibrahim 'alaihis salam tidak membiarkan istrinya pergi sendiri ke Makkah, beliau juga tidak meninggalkan istrinya tinggal bersama para wanita di asrama putri atau tinggal di terasteras masjidil Haram, dan beliau tidak pula meninggalkan istrinya tinggal serumah bersama orang-orang yang ikut tinggal di Makkah, namun beliau membiarkannya tinggal di tempatnya sendiri, istrinya dibiarkannya tinggal sendirian bersama bayinya yang bernama Isma'il 'Alaihis Salam, dan beliau tidak mencarikan pembantu untuk tinggal bersama keduanya, maka tidakkah kalian wahai orang-orang yang berakal untuk mengambil pelajaran dan contoh?, sebagaimana Allah berfirman dalam QS. Al-Mumtahanah/60: 4.

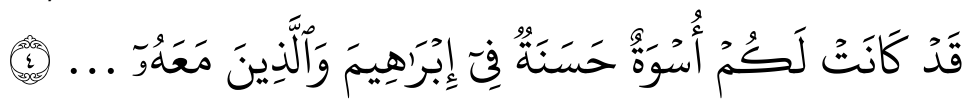

Terjemahnya:

Sungguh telah ada pada kalian suatu teladan yang bagus pada Ibrahim dan orang-orang yang bersamanya". 
Dari Ibnu Umar Radhiyallahu anhu, Rasulullah Shallallahu 'alaihi wa sallam, telah bersabda, "Artinya: Tidak diperbolehkan seorang wanita bepergian selama tiga hari melainkan bersamanya ada seorang muhrim". HR. Muttafaq 'alaih.

Dan dari Abu Said Al-Khudri Radhiyallahu'anhu, Rasulullah Shallallahu 'alaihi wa sallam bersabda, Artinya: "Tidak diperbolehkan seorang wanita bepergian selama dua hari melainkan bersamanya seorang muhrim darinya atau suaminya". HR. Muttafaq 'alaih.

Pendapat sebagian ulama ini (terutama ulama Saudi Arabia) lebih memandang kepada larangan Ikhtiladh (percampuran) antara lelaki dan wanita yang bukan mahram. Mereka pun tidak membolehkan wanita bekerja di tempat yang bercampur lelaki dan wanita (Dr Khalid Abd Rahman al-Juraisy: Fatwa Ulama alBalad al-Haram).

Makanya, di Saudi Arabia, terutama di Makkah, Madinah, dan Jeddah, tidak ada kelihatan wanita bekerja di tempat umum, seperti di plaza, mall, atau hotel.

Demikian ketentuan syariat yang saya kutip dari beberapa sumber. Sekarang masing-masing kita tinggal memilih dan menerapkannya sesuai dengan keperluan dan keadaan masingmasing. Insya Allah akan penuh hikmah membawa manfaat bagi para wanita.

\section{Perdebatan Pengiriman TKW ke luar negeri}

Perdebatan mengenai pengiriman TKW ke luar negeri bukanlah hal baru.Isu ini selalu muncul ketika terjadi masalah menyangkut nasib mereka di tempat kerjanya.Majelis Ulama Indonesia (MUI) bahkan pernah mengeluarkan fatwa haram terkait perempuan menjadi TKW.Ketentuan itu berlaku kalau kepergian perempuan itu tidak disertai mahram (pendamping).

Sangaji Jurnal Pemikiran Syariah dan Hukum 
Dalam fikih memang ada ketentuan bahwa seorang perempuan yang bepergian harus disertai mahram. Misalnya, dalam kitab Amal Al-Mar'ah fi Mizan Al-Syari'ah Al-Islamiyah (1978) karya Imad Hasan Abul Ainain disebutkan, haram hukumnya seorang perempuan Muslimah melakukan perjalanan sehari semalam tanpa disertai mahram atau suami meski untuk menunaikan ibadah haji yang wajib.

Ibnu Qudamah dalam al-Mughni bahkan menyatakan, siapa saja perempuan yang tidak punya mahram dalam perjalanan haji tidak wajib naik haji. Ada hadis, "Tidak halal perempuan yang beriman kepada Allah dan Hari Akhir melakukan perjalanan selama sehari semalam kecuali disertai mahramnya." Fatwa yang melarang perempuan bekerja sebagai TKW juga berangkat dari hukum asal bahwa perempuan tak boleh bekerja ke luar rumah.

Pandangan yang mengharamkan ini juga berdasarkan pertimbangan bahwa keberadaan TKW telah menjadi perantaraan munculnya berbagai hal yang diharamkan syara'.Misalnya, terjadinya pelecehan seksual, perkosaan, kekerasan, pembunuhan, pemotongan upah atau pungutan liar. Ada kaidah fikih, al-Wasilah ila al-Haram Muharramah, segala perantaraan yang mengakibatkan terjadinya keharaman hukumnya haram.

Berdasarkan status keharaman ini, pengiriman TKW ke luar negeri pun wajib dihentikan.Ini juga sesuai kaidah fikih al-Dharar yuzaal, segala macam bahaya wajib dihilangkan.Diantara lain, pandangan keharaman TKW untuk bekerja ke luar negeri dengan sebab hukum ('illat) tanpa mahram ini oleh berbagai kalangan dianggap membalik logika.

Pasalnya, kalau negara tak mampu memberikan perlindungan kepada buruh migran, khususnya perempuan, dan tidak mampu menyediakan lapangan kerja yang memadai di dalam negeri, mengapa perempuan yang dilarang bekerja di luar negeri? Masalah TKW perlu dilihat sebagai masalah ekonomipolitik daripada soal agama.Fatwa mengenai mahram lalu 
dipandang tidak operasional karena bertentangan dengan realitas sosial.Jutaan perempuan terpaksa harus bekerja ke luar rumah atau ke luar negeri karena kebutuhan perut yang tidak bisa dipenuhi oleh suami dan orangtua mereka.Pelarangan itu melanggar HAM karena setiap orang berhak mencari penghidupan yang layak.

Sudah sepatutnya digunakan hukum asal bahwa perempuan dan laki-laki boleh sama-sama bekerja di luar rumah.Dalam hukum agama disebutkan, bila ada yang membahayakan, baik terhadap perempuan dan laki-laki, kegiatan tersebut harus dihentikan sementara sampai bahaya itu bisa diatasi.Gangguan itu bisa bersifat personal atau berasal dari sistem.Gangguan yang berasal dari sistem adalah tanggung jawab pemerintah.

Setakat itu, lalu lahirlah apa yang disebut fikih sulthoni. Dalam fikih itu pemerintah diserahi tugas untuk menetapkan kebijakan.Misalnya, TKW tidak bisa dihentikan untuk bekerja karena kebutuhan ekonomi mereka. Dalam hal ini, pemerintah harus melindungi keselamatan mereka, bukan mengharamkan mereka pergi bekerja.

Hadis mengenai mahram berhubungan dengan keselamatan perempuan. Pandangan ini merupakan upaya reinterpretasi mengenai mahram. Maka, mahram dalam hal ini ditafsirkan mengacu kepada pemerintah dengan segala elemen dan kebijakannya yang memberi perlindungan kepada warga negara yang bekerja di luar negeri.

\section{Perlindungan Hukum terhadap TKW di Luar Negeri}

Pemerintah sebagai pelindung dan penanggung jawab masyarakatnya lalai dalam memenuhi kebutuhan warganya, padahal jelas sekali UU menyebutkan bahwa rakyat berhak memperoleh pekerjaan dan penghidupan yang layak. Kondisi kehidupan yang serba miskin ini, membuat para wanita 
memberanikan diri untuk mencari pekerjaan di luar negeri tanpa bekal pengetahuan dan skill sedikitpun.Karena di negeri sendiri mereka tidak memperoleh lapangan pekerjaan yang menjanjikan.Sementara para suami dan ayah mereka dinilai gagal dalam tanggung jawabnya sebagai kepala rumah tangga yang berkewajiban membiayai semua kebutuhan hidup anggota keluarganya. Ketika mereka masih bisa mencari pekerjaan dan penghasilan, maka para wanita tidak perlu keluar untuk mencari penghasilan tambahan lain, apalagi berkerja selama bertahuntahun di luar negeri sebagai pembantu rumah tangga. ${ }^{23}$

Jika ditelaah melalui data Komnas Perempuan selama lima tahun terakhir, kasus kekerasan dalam rumah tangga (KDRT) merupakan bentuk kekerasan yang terbanyak dialami perempuan dari tahun ke tahun, dan bentuk yang paling sering ditangani oleh Pengadilan Agama adalah penelantaran ekonomi (61\%). Penelantaran ekonomi dirasakan oleh perempuan secara langsung karena, 60\% pengelola struktur pengeluaran rumah tangga adalah perempuan, maka dampak pemangkasan kebutuhan ekonomis langsung bersinggungan pada mereka. Kelompok perempuan sebagai pengelola Rumah Tangga, menerapkan ragam strategi untuk mengatasi keterbatasan ekonomi .Hingga akhirnya mendesak kaum perempuan untuk mencari kerja di luar negeri. Hal ini dipengaruhi oleh imingiming peluang mendapatkan upah yang relatif tinggi serta desakan keluarga untuk memperbaiki kualitas hidup, yang kemudian semakin mendorong perempuan, dalam hal ini istri ataupun anak perempuan, untuk meninggalkan keluarganya guna bekerja sebagai buruh migran.

Namun, kenyataan bahwa sebagian besar buruh migran adalah kelompok perempuan berpendidikan rendah, maka pilihan pekerjaan yang tersedia sangat terbatas.Mereka akhirnya

${ }^{23}$ Santoso, Birokrasi dan Masyarakat Indonesia(Jakarta), h. 367. 
bekerja di sektor pekerjaan domestik, yang masih identik dengan "pekerjaan perempuan". Hal ini terlihat dari kenyataan bahwa sebagian besar (sekitar 90\%) buruh migran perempuan bekerja di sektor domestik, terutama sebagai pekerja rumah tangga. Pada tahun 2006, CATAHU Komnas Perempuan mencatat sebanyak 1.259 buruh migran Indonesia -yang kebanyakan adalah perempuan- mengalami berbagai bentuk pelanggaran, seperti diskriminasi, eksploitasi, dan kekerasan.

Di tengah terobosan-terobosan kebijakan di bidang pemberian layanan bagi perempuan korban kekerasan di Indonesia (12 produk kebijakan di tingkat lokal hingga nasional), ternyata buruh migran perempuan sama sekali luput dari penyikapan yang serius dan sistematik dari pemerintah. Selama tahun 2006, kasus-kasus buruh migran masih didominasi oleh persoalan konflik perburuhan lainnya, yang meliputi gaji tidak dibayar, gaji dibawah standar upah, serta kerja melebihi jam kerja. Meskipun telah lahir sebuah Memorandum of Understanding $(\mathrm{MoU})$ antara pemerintah Indonesia dan Malaysia tentang pekerja Rumah Tangga Indonesia, namun pemerintah tetap tidak dapat memenuhi standar perlindungan yang cukup bagi buruh migran, khususnya buruh migran perempuan. ${ }^{24}$

Kebijakan menghentikan pengiriman TKW menjadi tidak bijaksana ketika kita mencoba menelaah kembali akar permasalahan dan faktor pendorong banyaknya perempuan Indonesia yang ingin bekerja ke luar negeri. Selama pemerintah masih belum bisa mengatasi kemiskinan, dan menyejahterakan warganya, maka jangan harap kebijakan penghentian TKW akan mampu meredam masalah. Ini justru akan menimbulkan dampak lebih besar di Indonesia, karena pengangguran jelas akan semakin bertambah.

${ }^{24}$ Arif Budiman, Negara Dan Pembangunan (Jakarta, 1986,) h. 32.

Sangaji Jurnal Pemikiran Syariah dan Hukum 
Maka daripada itu, berdasarkan identifikasi masalah yang ada di dalam negeri, maka langkah-langkah kebijakan yang bisa dilakukan pemerintah sebagai berikut:

1. Mengubah image negative TKW dan TKI, bahwa TKW dan TKI yang bekerja sebagai pembantu rumah tangga adalah posisinya rendah di masyarakat. Pemerintah bisa mengeluarkan statement atau bahkan di bisa dimasukkan ke dalam Undang-Undang mengenai definisi tenaga kerja Indonesia. Bahwa, TKI adalah pekerjaan yang sangat membantu Negara dalam memperbesar cadangan devisa. Hal ini penting agar masyarakat tidak menganggap remeh posisi pembantu rumah tangga. Bukan hanya masyarakat Indonesia, tetapi juga yang lebih penting adalah masyarakat di Negara penerima TKW. Supaya tindakan pelecehan tidak terulang lagi.

2. Memperkuat hubungan bilateral antara pemerintah Indonesia dengan pemerintah negera penerima TKW dan TKI. Terutama dalam menyangkut masalah TKI. Perlu ada semacam consensus, perjanjian, atau kontrak kerja bersama yang di dalamnya termuat sejumlah peraturan mengenai TKI dan TKW. Juga hak-hak yang harus di dapat TKW selama nekerja di luar negeri, tentang sanksi-sanksi dan aturan atas tindak pidana yang bisa dilakukan oleh majikan ataupun TKW itu sendiri.

3. Menyusun Undang-Undang yang khusus mengatur masalah TKW. Karena selama ini masalah TKI ada di bawah UU Tenaga Kerja yang disitu belum ada aturan yang jelas tentang TKW, batas jam kerja TKI, maupun jenis-jenis perlindungan terhadap TKI. 
4. Memperbaiki kualitas pendidikan di Indonesia dengan merealisasikan anggaran pendidikan sebesar 20\%. Hal ini baru terasa sekali ketika ternyata banyak sekali para TKW yang minim pengetahuan sehingga mudah dibodohi para calo, dan majikan mereka. Sehingga akhirnya mereka menjadi korban pelanggaran HAM di tempat mereka bekerja.

5. Menetapkan kebijakan pengiriman TKW yang mempunyai skill. TKI atau TKW yang mempunyai skill tidak akan mudah mendapatkan pelanggaran HAM di negeri penerima.

6. Penetapan dan sosialisasi mengenai prosedur resmi pemberangkatan tenaga kerja Indonesia dan penempatannya. Agar tidak ada lagi calon TKW atau TKI yang tertipu oleh para calo atau di tempatkan di tempat kerja yang salah. Sosialisasi ini harus menjangjau sampai ke calon TKW, jika tidak, maka kejadian penipuan dan pelanggaran HAM akan terus berlanjut sampai kapanpun.

7. Untuk menghindari adanya lembaga penyalur TKW yang tidak resmi, maka pemerintah perlu menetapkan standarisasi dan akreditasi terhadap Penyalur Jasa Tenaga Kerja Indonesia (PJTKI) yang ada atau yang akan didirikan. Dan yang memenuhi akreditasilah yang berhak menjadi lembaga penyalur tenaga kerja nantinya. Lembaga-lembaga penyalur ini perlu juga di sosialisasikan kepada masyarakat dan calon TKW agar masyarakat yang ingin menjadi TKW/TKI mendaftar di PJTKI yang sudah diresmikan oleh Negara.

8. Pengaturan mekanisme yang jelas tentang perlindungan TKW di luar negeri dan hal ini perlu di sosialisasikan kepada para TKW sebelum di berangkatkan mengenai hak-hak mereka dan bagaimana prosedur yang harus dilakukan untuk 
mendapatklan perlindungan hokum ketika terjadi pelanggaran HAM pada mereka.

9. Dengan diberlakukan otonomi daerah di Indonesia, pemerintah bisa mengarahkan pemerintah daerah agar bisa memaksimalkan potensi TKW yang baru saja pulang dari luar negeri, agar para mantan TKW ini tidak kehilangan pekerjaan selepas pulang dari luar negeri. Pemanfaatan skill yang sudah dimiliki TKW oleh Pemda akan membantu peningkatan perekonomian mereka dan secara tidak langsung akan mengurangi jumlah kemiskinan di daerah masing-masing.

10. Pemerintah melakukan pengawasan yang ketat terhadap PJTKI, terutama pada waktu memberikan penyuluhan dan pelatihan bagi para calon TKW. Agar sosialisasi dan pelatihan benar-benar tepat sasaran dan tersampaikan secara benar kepada para calon TKW.

11. Membangun jaringan kerjasama dengan NGO / LSM, dan PJTKI resmi dalam pengelolaan TKW. NGO berperan dalam proses monitoring, riset data, dan pembelaanhukum dan pendampingan terhadap TKW. Sementara itu, PJTKI berperan penuh dalam memberikan pemahaman mengenai skill dan peraturan-peraturan lain kepada TKW.

Dalam hal ini Komnas Perempuan juga menyatakan beberapa rekomendasi dalam merespon hal tersebut: ${ }^{25}$

1. Pemerintah Indonesia perlu mengeluarkan kebijakan untuk memberlakukan perlindungan bagi perempuan, dalam kaitannya terhadap isu KDRT juga Perlindungan Tenaga Kerja Indonesia sebagai Buruh Migran.

${ }^{25}$ Arif Budiman, Negara Dan Pembangunan,h. 32. 
2. Pemerintah tidak lagi menyelesaikan kasus Buruh Migran secara kasus per kasus, namun lebih komprehensif hingga dapat melindungi keberlanjutan hak buruh migran ke depan.

3. Dalam penanganan Kasus KDRT, Pemerintah perlu upaya sistematis untuk memberi rehabilitas ekonomi bagi perempuan pengelola rumah tangga.

Oleh karenanya, Lembaga ulama di negara pernah memutuskan seperti ini:

KEPUTUSAN FATWA MUSYAWARAH NASIONAL VI MAJELIS ULAMA INDONESIA NOMOR: 7/MUNAS VI/MUI/ 2000 TENTANG PENGIRIMAN TENAGA KERJA WANITA (TKW) KE LUAR NEGERI

\section{MEMUTUSKAN:}

1. Perempuan yang meninggalkan keluarga untuk bekerja ke luar kota atau ke luar negeri, pada prinsipnya, boleh sepanjang disertai mahram, keluarga ataulembaga / kelompok perempuan terpercaya(niswan tsiqah).

2. Jika tidak disertai mahram (keluarga) atau niswah tsiqah, hukumnya haram, kecuali dalam keadaan darurat yang benarbenar bisa dipertanggungjawabkan secara syar'iy, qanuniy, dan 'adiy, serta dapat menjamin keamanan dan kehormatan tenaga kerja wanita.

3. Hukum haram berlaku pula kepada pihak-piha $\mathrm{k}$, lembaga atau perorangan yang mengirimka $\mathrm{n}$ atau terlibat dengan pengiriman TKW seperti dimaksud angka 2; demikian juga pihak yang menerimanya.

4. Mewajibkan kepada pemerintah, lembaga dan pihak lainnya dalam pengiriman TKW untuk menjamin dan melindu 
keamanan dan kehormatan TKW, serta members kelompok / lembaga perlindungan hukum atau kelompok niswan tsigah di setiap negara tertentu, serta kota-kota tertentu untuk menjamin dan melindungi keamanan serta kehormatan TKW.

5. Keputusan fatwa ini mulai berlaku pada tanggal ditetapkan, agar setiap orang dapat mengetahui nya / menghimbau semua pihak untuk menyebarluaskan fatwa ini. ${ }^{26}$

\section{Simpulan}

Tenaga kerja merupakan penduduk yang berada dalam usia kerja. Menurut UU No. 13 tahun 2003 Bab I pasal 1 ayat 2 disebutkan bahwa tenaga kerja adalah setiap orang yang mampu melakukan pekerjaan guna menghasilkan barang dan atau jasa baik untuk memenuhi kebutuhan sendiri maupun teks miring untuk masyarakat.Secara garis besar penduduk suatu negara dibedakan menjadi dua kelompok, yaitu tenaga kerja dan bukan tenaga kerja.

TKW (Tenaga Kerja Wanita) adalah TKI (Tenaga Kerja Indonesia) perempuan warga negara Indonesia yang bekerja di luar negeri dalam hubungan kerja untuk jangka waktu tertentu dengan menerima upah. TKW sering disebut pahlawan devisa karena dalam setahun dapat menghasilkan devisa 60 triliun rupiah (data 2006).

Bagi Indonesia karena begitu banyak TKW yang menghadapi kesulitan, termasuk karena banyak yang tidak mempunyai paspor, izin masuk dari negara yang dimasuki, malah ada yang sama sekali menjadi migran ilegal. Di antara yang sangat menderita itu, tampaknya adalah TKW ilegal, yang bagai tidak dapat dilindungi oleh negeri asal, dan tidak pula dapat dilindungi oleh negeri tetangga.Namun berbagai masalah

${ }^{26}$ Fatwa MUI Ditetapkan di Jakarta 27 Rabi'ul Akhir 1421 H - 29 Juli 2000. 
dihadapi oleh TKW asal Indonesia di negara mereka bekerja. Perlindungan hukum tak memandang mereka, bahkan sering penyiksaan mereka rasakan.

Menjadi TKW yang bekerja di luar negeri hukumnya haram, berdasarkan 2 (dua) alasan utama: pertama, karena TKW telah bekerja di luar negeri tanpa disertai mahram atau suaminya. Padahal syara' telah mengharamkan seorang perempuan muslimah melakukan perjalanan (safar) sehari semalam tanpa disertai mahram atau suami, meski untuk menunaikan ibadah haji yang wajib.

Kedua, menjadi TKW juga haram ditinjau dari segi lain, yaitu keberadaan TKW telah menjadi perantaraan munculnya berbagai hal yang diharamkan syara'. Misalnya, terjadinya pelecehan seksual, perkosaan, kekerasan, pembunuhan, pemotongan upah, dan pungutan liar.Semua ini telah diharamkan oleh syara' berdasarkan dalilnya masing-masing. Maka, menjadi TKW hukumnya haram berdasarkan kaidah fiqih Al-Wasilah ila al-Haram Muharramah(segala perantaraan yang mengakibatkan terjadinya keharaman, hukumnya haram).

\section{Daftar Pustaka}

'Ainain, Imad Hasan Abul. 'Amal Al-Mar'ah fi Mizan Al-Syari'ah Al-Islamiyah.

al-Bar, M. Ali. Amal Al-Mar’ah fi Al-Mizan.

Budiman,Arif.Negara Dan Pembangunan.Jakarta, 1986.

Fatwa MUI Nomor: 7/MUNAS VI/MUI/ 2000 tentang Pengiriman

Tenaga Kerja Wanita (TKW) ke Luar Negeri.

Http://dilihatya.com/1762/pengertian-tenaga-kerja-menurut-paraahli. diakses pada tanggal 2 Mei 2017, Pukul 11:10.

Http/ilhamrizki.com/2013/criteria dasar memilih calon tenaga kerja. diakses pada tanggal 2 Mei 2017, Pukul 11:15.

Husni, Lalu. Hukum Ketenagakerjaan Indonesia(Jakarta;PT. Raja Grafindo Persada,2007.

Sangaji Jurnal Pemikiran Syariah dan Hukum 
Ismail, M. Bakar. Al-Qawa'id Al-Fiqhiyyah Bayna Al-Ashalah wa Al-Taujih.

Al-Musaimiri, Riyadh Muhammad. 'Amal Al-Mar'ah Bayna AlMasyru' wa Al-Mamnu'.

an-Nabhani, Taqiyuddin. An-Nizham al-Ijtima'i fi Al-Islam.

Santoso, Birokrasi dan Masyarakat Indonesia(Jakarta).

Soepomo, Imam. Pengantar Hukum Perburuhan. Jakarta:

Djambatan, 1992.

Suratman, Hukum Ketenagakerjaan Indonesia. Jakarta: PT. Indeks, 2010.

Suyuthi, Imam. Al-Asybah wa Al-Nazha `ir.

Tjitrosono, R. Subekti R. Kitap undang-undang perdata (Jakarta:Pradayana Paramita,1963.

Undang-Undang Ketenagakerjaan No. 13 Tahun 2003.

Undang-Undang Penempatan dan Perlindungan Tenaga Kerja Indonesia di Luar Negeri No. 39 Tahun 2004. 